\title{
Leptin-induced ER-a-positive breast cancer cell viability and migration is mediated by suppressing CCN5-signaling via activating JAK/AKT/STAT-pathway
}

Inamul Haque ${ }^{1,2+}$, Arnab Ghosh ${ }^{1,2+}$, Seth Acup ${ }^{1}$, Snigdha Banerjee ${ }^{1,4,7^{*}}$, Kakali Dhar ${ }^{1,5,6}$, Amitabha Ray ${ }^{1,5,6}$, Sandipto Sarkar ${ }^{1,2}$, Suman Kambhampati ${ }^{1}$ and Sushanta K. Banerjee ${ }^{1,2,3,4,7^{*}}$

\begin{abstract}
Background: In menopausal women, one of the critical risk factors for breast cancer is obesity/adiposity. It is evident from various studies that leptin, a $16 \mathrm{kDa}$ protein hormone overproduced in obese people, plays the critical role in neovascularization and tumorigenesis in breast and other organs. However, the mechanisms by which obesity influences the breast carcinogenesis remained unclear. In this study, by analyzing different estrogen receptor-a (ER-a)-positive and ER-a-negative BC cell lines, we defined the role of CCN5 in the leptin-mediated regulation of growth and invasive capacity.

Methods: We analyzed the effect of leptin on cell viability of ER-a-positive MCF-7 and ZR-75-1 cell lines and ER-a-negative MDA-MB-231 cell line. Additionally, we also determined the effect of leptin on the epithelialmesenchymal transition (EMT) bio-markers, in vitro invasion and sphere-formation of MCF-7 and ZR-75-1 cell lines. To understand the mechanism, we determined the impact of leptin on CCN5 expression and the functional role of CCN5 in these cells by the treatment of human recombinant CCN5 protein(hrCCN5). Moreover, we also determined the role of JAK-STAT and AKT in the regulation of leptin-induced suppression of CCN5 in BC cells.

Results: Present studies demonstrate that leptin can induce cell viability, EMT, sphere-forming ability and migration of MCF-7 and ZR-75-1 cell lines. Furthermore, these studies found that leptin suppresses the expression of CCN5 at the transcriptional level. Although the CCN5 suppression has no impact on the constitutive proliferation of MCF-7 and ZR-75-1 cells, it is critical for leptin-induced viability and necessary for EMT, induction of in vitro migration and sphere formation, as the hrCCN5 treatment significantly inhibits the leptin-induced viability, EMT, migration and sphere-forming ability of these cells. Mechanistically, CCN5-suppression by leptin is mediated via activating JAK/AKT/ STAT-signaling pathways.

Conclusions: These studies suggest that CCN5 serves as a gatekeeper for leptin-dependent growth and progression of luminal-type (ER-positive) BC cells. Leptin may thus need to destroy the CCN5-barrier to promote BC growth and progression via activating JAK/AKT/STAT signaling. Therefore, these observations suggest a therapeutic potency of CCN5 by restoration or treatment in obese-related luminal-type BC growth and progression.
\end{abstract}

Keywords: Leptin, CCN5, Breast cancer, Proliferation, Invasion and migration

\footnotetext{
* Correspondence: sbanerjee@kumc.edu; sushanta.banerjee@va.gov;

sbanerjee2@kumc.edu; cancerresearchunit@icloud.com

${ }^{\dagger}$ Equal contributors

${ }^{1}$ Cancer Research Unit, VA Medical Center, Kansas City, MO, USA

Full list of author information is available at the end of the article
} 


\section{Background}

Breast cancer (BC) is a genetically heterogeneous disease; it is the most frequently diagnosed and the second leading cause of cancer-related death in women in the United States and globally [1-3]. It attacks one in eight women $(\sim 12 \%)$, impacting nearly every family worldwide [4-7]. In both pre- and post-menopausal women, one of the important risk factors for $\mathrm{BC}$ is obesity [8-11], which is associated with increased risk of recurrence, resistance to chemotherapy, poorer survival and overall adverse disease prognosis [12-14]. The mechanisms through which obesity may influence the disease process include an excess production of estrogen by adipose tissue aromatase (peripheral aromatization), reduced levels of sex hormone-binding globulin with consequent rise of the bioactive/free estradiol, increased biosynthesis of insulin-like growth factors (IGFs) and adipose tissue secreted factors like leptin, which is involved in various physiological functions such as sense of satiety, energy metabolism, fertility, immune response and hematopoiesis $[15,16]$. The action of leptin is mediated via its receptor $(\mathrm{Ob}-\mathrm{R})$ that in turn can stimulate the signaling pathways like Jak/Stat3, ERK1/2, and PI3 Kinase/ Akt [17-19]. Additionally, leptin can crosstalk with other signaling systems in $\mathrm{BC}$ cells $[20,21]$. The studies have shown higher serum levels of leptin in patients with $\mathrm{BC}$ [22-25]. Furthermore, leptin over-expression in BC has been found to be associated with more aggressive clinical features [26-28]. Several investigators observed a stimulating effect of leptin on aromatase activity [29-31], and activation of ER $\alpha$ in BC cells [32]. However, in contrast, the elevated levels of leptin may provide resistance to anti-estrogen therapy in $\mathrm{BC}$ patients [33]. The leptin signaling may promote abnormal angiogenesis and permeability as leptin has been shown to stimulate the expression of vascular endothelial growth factor (VEGF) and its receptor [34]. Furthermore, the invasive properties of BC cells have been shown to augment by leptin through a novel bidirectional crosstalk between leptin and IGF-I signaling that could transactivate epidermal growth factor receptor (EGFR), an important member of HER2/neu family [35]. A robust influence of leptin on extracellular matrix (ECM) has been demonstrated [36]. It is known that different components of ECM constitute the tumor microenvironments that significantly affect the pathological process of tumor invasion as well as progression. Thereby, leptin-mediated regulation of ECM proteins may help in promoting invasion and metastasis in $\mathrm{BC}$.

A group of ECM-associated cysteine-rich proteins that belong to the CCN (Cyr61, CTGF, -Nov) family of growth factor have recently emerged as multifunctional molecules, which modulate various cellular functions [37-39]. CCN5 (WISP-2) is a multi-modular-matricellular protein $(\sim 29-35 \mathrm{kDa})$ with a long half-life, and a member of the
CCN family [38, 40-42]. The transient expression of CCN5 has been detected in fetal lung, adult skeletal muscle, colon, ovary, and breast [38, 43, 44]. CCN5 has been implicated as having an important role in carcinogenesis, with particular relevance to human breast disease [38, 41, 45-48]. In most studies, CCN5 expression has been shown to correlate inversely with the aggressiveness of cancers in breast $[38,49,50]$, pancreas [51, 52], salivary gland [53], gallbladder [54] and gastric tissue [55], suggesting tumor suppressor/anti-invasive activity [38, 41, 52]. Thus, at least in BC, CCN5 can be considered a good prognostic marker [44]. Multiple studies have shown that CCN5-overexpressed $\mathrm{BC}$ cells are less aggressive in nature compared to CCN5-under expressed or negative BC cells [38]. CCN5 expressing BC cells (e.g. MCF-7, BT-474, ZR$75-1, T-47 \mathrm{D})$ are always ER- $\alpha$ positive (luminal type), while CCN5-negative cells are mostly triple-negative (ER-, PR- HER2-)-breast cancer (TNBC) cells (e.g. MDA-MB231, MDA-MB-468, HCC-70, BT-20, MVT-1 and 4 T1) $[38,46,52]$, which are enriched with tumor initiating cells (TICs)/cancer stem cells. Mechanistically, multiple genetic insults, including the gain of p53 mutations, deplete CCN5 expression at the transcription level in noninvasive BC cells and help cells gain invasive phenotypes [56]. Moreover, several oncogenic lesions such as miR-10b upregulation and activation of TGF- $\beta$-signaling can accumulate during CCN5 crisis in BC cells $[38,48,57]$.

CCN5 regulation in ER- $\alpha$-positive cells is estrogen, an insulin-like growth factor and HIF- $\alpha 2$-dependent, and its expression has been found to participate in controlling proliferation as well as the aggressive phenotypes of these cells $[38,44,50]$. Thereby, CCN5 depletion in ER- $\alpha-$ positive cells promotes estrogen-independent growth, epithelial-mesenchymal transition (EMT), and stemness, consistent with more invasive phenotypes and display similarities to TNBC. In contrast, ectopic expression of CCN5 in TNBC cells reduced growth/proliferation, tumorforming ability, invasiveness and sensitivity to tamoxifen by activating ER- $\alpha$, demonstrating similarities to ER- $\alpha$ positive, non-aggressive BC cells $[44,47,58]$. Thus, these studies reveal that the CCN5-signaling could be a driving force to prevent TNBC growth and aggressiveness [44].

Given the tumor suppressor and anti-invasive roles of CCN5 in BC, we used molecular techniques to investigate whether leptin has any influence on CCN5 to promote $\mathrm{BC}$ progression. We found that leptin suppresses CCN5 in BC cells to promote its pathobiological functions. The suppression of CCN5 is mediated through JAK/STAT3-Akt signaling pathway.

\section{Methods}

\section{Reagents and antibodies}

Dulbecco's modified Eagle's medium (DMEM), penicillin, streptomycin, Aprotinin, PMSF, Leupeptin, trypsin 
EDTA solution, sodium pyruvate, $17 \beta$-estradiol (E2), leptin and $\beta$-actin monoclonal antibodies were purchased from Sigma Chemical Co. (St. Louis, MO, USA). Human recombinant CCN5 protein (hrCCN5) was purchased from PeproTech (Rocky Hill, NJ, USA). Anti- Ecadherin and anti-vimentin antibodies were purchased from BD Biosciences (Franklin Lakes, NJ, USA) and Thermo Fisher Scientific (Waltham, MA, USA), respectively. Anti-WISP-2/CCN5 rabbit polyclonal antibody and Anti-Snail antibody were purchased from Abcam (Cambridge, MA, USA). Super Signal ULTRA chemiluminescent substrates were obtained from Pierce, Rockford, IL. Cell-death detection ELISA kits were purchased from Roche Diagnostic (Indianapolis, IN). The authentication certificates for all these chemicals, drugs and antibodies were provided by these companies. The fresh working solutions of the chemicals and drugs were prepared once a month to guarantee effectivity.

\section{Cell lines and cell culture}

The estrogen receptor- $\alpha$ (ER- $\alpha$ ) positive MCF-7, ZR-751 cell lines and MDA-MB-231 triple negative breast cancer $(\mathrm{TNBC})$ cell lines were purchased from American Type Culture Collections (ATCC, Manassas, VA) and grown in Dulbecco's modified Eagle's medium (Sigma Chemical Co., St. Louis) supplemented with $10 \%$ fetal bovine serum (FBS) (HyClone, Road Logan, UT) and antibiotics at $37{ }^{\circ} \mathrm{C}$ in a humidified chamber with $5 \% \mathrm{CO}_{2}$. Initially, cells were grown in complete media until the culture became $\sim 60-70 \%$ confluent. For all experiments unless otherwise specified, the medium was changed into serum and phenol red-free media. Then $24 \mathrm{~h}$ later, the medium was changed into serum and phenol red-free media, and the cells were treated with Leptin or hrCCN5 or combination as per the requirements of the experiments.

\section{Cell viability assay}

Cell viability assay was performed as described earlier [59, 60]. Briefly, MCF-7, ZR-75-1 and MDA-MB-231 were plated with $1 \times 10^{4}$ live cells per well in 96-well culture plate. Plates were maintained at $37{ }^{\circ} \mathrm{C}$ in a humidified atmosphere with $5 \% \mathrm{CO}_{2}$. About $60-70 \%$ confluent cells were serum-starved for $24 \mathrm{~h}$ to synchronized them. Cells were then treated with different doses of leptin or hrCCN5 protein $(10.29 \mathrm{nM})$ or both for different time points in serum free DMEM as needed for the experiments. Cells were stained with crystal violet solution for $10 \mathrm{~min}$. Cells were washed with tap water and then air dried for $30 \mathrm{~min}$. Crystal violet stained cells were solubilized with $10 \%$ acetic acid and optical density was quantitated in Microplate reader at $600 \mathrm{~nm}$. Eight wells were examined for each condition, and the experiments were repeated three times.

\section{Apoptosis assay}

Photometric enzyme immunoassay for quantitative in vitro determination of cytoplasmic histone-associated DNA fragment after apoptotic cell death was determined as described previously [61]. Briefly, MCF-7 cells and ZR-75-1 serum starved cells were treated with leptin (3.125 nM) for $48 \mathrm{~h}$. Cells were harvested and lysed with lysis buffer supplied with cell-death detection ELISA kits (Roche Diagnostic Corporation, Indianapolis, IN). The cytoplasmic supernatant was collected, and the total protein was estimated. A total of $20 \mu \mathrm{l}$ of cell lysate containing 12-15 $\mu \mathrm{g}$ of protein was added in the streptavidin-coated microplate and allowed to react with $80 \mu \mathrm{l}$ of buffer mixture containing anti-histone-biotin and anti-DNA-peroxidase was added and incubated on shaker under gently shaking for $2 \mathrm{~h}$ at $25{ }^{\circ} \mathrm{C}$. Microplates were washed with incubation buffer for 3 times. The ABTS [2, 2'-azino-di-(3-ethyl-benzthiazoline-6-sulfonic acid)] chromogen substrate solution was added and allowed to incubate on plate shaker until the color development is sufficient for a photometric analysis (approximately $10-15 \mathrm{~min}$ ). Color intensity was measured using ELISA plate reader (Spectramax 340, Molecular Devices) at $405 \mathrm{~nm}$.

\section{Western blot analysis}

Treated or untreated cells were washed with phosphate buffered saline (PBS) and lysed in $50 \mathrm{mM}$ Tris- $\mathrm{HCl}$ at $\mathrm{pH}$ 7.5, $150 \mathrm{mM} \mathrm{NaCl}, 0.1 \%$ SDS, $1 \mathrm{mM}$ PMSF, $1 \mathrm{ng} / \mathrm{ml}$ leupeptin and $1 \mathrm{ng} / \mathrm{ml}$ Aprotonin or phospho-lysis buffer, sonicated for $3 \mathrm{~s}$ and incubated on ice for $20 \mathrm{~min}$. The lysates were centrifuged at $18,000 \mathrm{~g}$ for $60 \mathrm{~min}$ at $4{ }^{\circ} \mathrm{C}$, and the supernatants were collected and Western immunoblotting were performed as described earlier [62]. Briefly, equal amounts of proteins were resolved on $7.5 \%$ or $10 \%$ SDS-PAGE, transferred onto nitrocellulose membranes, and reacted with specific primary antibodies at $4{ }^{\circ} \mathrm{C}$, overnight. The antigen-antibody reactions were probed with HRP-conjugated anti-rabbit or anti-mouse IgG. Immunoreactions were detected by ECL chemiluminescence reagent kit. Relative expressions of proteins were calculated by densitometric analyses using ID Image Analysis Software version 3.6 (Eastman Kodak Company, Rochester, NY).

\section{RNA extraction and real-time RT PCR}

Total RNA extraction and cDNA synthesis, were essentially the same as that previously described [63]. Briefly, total RNA was extracted from MCF-7 cell lines using TRIZOL (Invitrogen, Carlsbad, CA) as per the manufacturer's protocol. $500 \mathrm{ng}$ of total RNA was reverse transcribed using oligo $d(T)_{16}$ primers. Real-time PCR was performed on an Applied Biosystem Step One real-time PCR system (Foster City) using SYBR Green DNA 
detection dye. PCR was performed for $15 \mathrm{~s}$ at $95{ }^{\circ} \mathrm{C}$ and $1 \mathrm{~min}$ at $60{ }^{\circ} \mathrm{C}$ for 40 cycles followed by the thermal denaturation protocol. $\mathrm{C}_{\mathrm{T}}$ values for WISP2/CCN5 are normalized to human GAPDH by subtracting the average $C_{T}$ value for each sample. Relative quantification (RQ) values for CCN5 mRNA in experimental samples were determined using the $2^{-\Delta \Delta C T}$ method [64]. The sequences of primers are as follows: WISP-2/CCN5: 5'CCT ACA CAC ACA GCC TAT ATC-3' (forward) and 5'-CCT TCT CTT CAT CCT ACC-3' (backward); GAPDH: 5' -ATG AGA AGT ATG ACA ACA GCC-3' (forward) and 5'-TGA GTC CTT CCA CGA TAC C-3' (backward).

\section{Northern blot analysis}

The nonradioactive Northern blot analysis was carried out per our previous method [62]. Briefly, total RNA was separated on $1 \%$ agarose gels containing $2.2 \mathrm{M}$ formaldehyde in MOPS buffer and blotted on super charged nylon membranes (Schleicher \& Schuell Inc. Keene, NH). Membranes were probed with nonradioactive DIG-labeled human WISP-2/CCN5- and glyceraldehydes-3-phosphate dehydrogenase (GAPDH)-specific cDNA probes. The rest of the procedure was carried out per the protocols provided by DIG high prime DNA labeling and detection kit (Roche Diagnostics GmbH, Indianapolis, IN). The signal intensities of WISP-2/CCN5 and GAPDH were measured by densitometric analysis using one-dimensional image analysis software (Kodak Image Station, version 3.6) for normalization.

\section{Transwell cell migration assay}

Cell migration assay was performed per the method described by Maity et al. [59]. Briefly, semiconfluent MCF7 and ZR-75-1 cells were serum starved for $24 \mathrm{~h}$ prior to the treatments and then under serum starved conditions cells were exposed to leptin $(3.125 \mathrm{nM})$ or vehicle (1xPBS) in the presence or absence of hrCCN5 $(10.29 \mathrm{nM})$ for $48 \mathrm{~h}$. Cells $(10,000$ per well) were then seeded on transwell filter insert of $8-\mu \mathrm{m}$ pore size (Becton Dickinson) coated with fibronectin $(10 \mu \mathrm{g} / \mathrm{ml})$. DMEM with no serum was added into the upper wells while DMEM with 10\% FBS were added into the bottom chamber. The cells were incubated overnight for migration towards serum at $37^{\circ} \mathrm{C}$ with $5 \% \mathrm{CO}_{2}$. Cells adherent to the upper surface were removed with cotton swabs, and migratory cells attached on the undersurface were stained with crystal violet solution. Wells were gently rinsed with water and dried in the air. Crystal violetstained attached cells were solubilized with $100 \mu \mathrm{l}$ of $10 \%$ acetic acid and cell migration towards serum was quantitated using microplate reader at $600 \mathrm{~nm}$.
Chloramphenicol acetyltransferase assays

Chloramphenicol acetyltransferase (CAT) assay, using CAT-ELISA kits (Roche Applied Science, Inc.), was performed same as described previously [65, 66]. Briefly, CCN5/WISP-2-CAT promoter constructs (pCCN5-CAT, cloned into the pCAT-3-Basic Vector, Promega) containing the 1.9-kb human CCN5 gene promoter sequence $(-1919$ to +13$)$ were transiently transfected into the MCF-7 cells using the Lipofectin $(20 \mu \mathrm{g} / \mathrm{ml})$ method [62]. After $48 \mathrm{~h}$, transfected cells were grown in serumdeprived media and exposed to leptin (3.125 nM) for $48 \mathrm{~h}$. Cells were harvested, and cellular extracts were prepared for CAT assays per the manufacturer's instructions. CAT activity was measured at $405 \mathrm{~nm}$ using a microplate (ELISA) reader (Spectramax 340, Molecular Devices).

\section{Mammosphere assays}

A mammosphere assay was performed as described recently [59] with little modification. Briefly, MCF-7 cells were grown in serum starved media as described earlier and treated with leptin $(3.125 \mathrm{nM})$ or vehicle $(1 \mathrm{xPBS})$ in the presence or absence of hrCCN5 $(10.29 \mathrm{nM})$ for $48 \mathrm{~h}$. Cells were then seeded $(0.5 \mathrm{cell} / \mathrm{ml} /$ well $)$ into a 96 -wellnon-adherent micro-space cell culture plate (Elplasia, Kuraray, Co., Ltd., SQ200100NA96, Japan) containing Mammocult media (Stem Cell Technologies) with proliferation supplements, $4 \mu \mathrm{g} / \mathrm{ml}$ heparin and $0.48 \mu \mathrm{g} / \mathrm{ml}$ hydrocortisone. Single cell suspensions were allowed to grow and mammospheres were counted at day six following seeding the cells. Photographs were taken using a Leica photomicroscope, and sizes were determined using NIS-Elements software.

\section{Statistical analysis}

The statistical analysis was performed using the Graph Pad Prism 4 software and PASS ${ }^{15}$ softwares. We calculated the required sample size for in vitro studies using an approximate method [67] is $n=3-8$ cultures per groups and time point, assuming comparison-wise type I error of $5 \%$ and power of $80 \%$ to detect the probability of concordance of $75 \%$. All data are expressed as the mean \pm SEM. Statistically significant differences between groups were determined by using the nonpaired Student's two-tailed $t$-test and ANOVA as per the requirement. A value of $P<0.05$ was considered statistically significant.

\section{Results}

Leptin induces ER-a-positive BC cell viability in a dose and time dependent fashion

Previously, it has been reported that leptin promotes MCF-7 cell growth [27, 36, 68, 69]. In this study, our goal was to investigate the effect of leptin on cell 
viability of different $\mathrm{ER}$ - $\alpha$-positive and triple negative $\mathrm{BC}$ cell lines. To do so, ER- $\alpha$ positive cells (MCF-7 and ZR75) and TNBC cells (MDA-MB-231) were serumstarved for $24 \mathrm{~h}$ to synchronized the cells and then treated with different doses of leptin (i.e. 0, 0.313, 0.626, $3.125,6.25,31.25 \mathrm{nM})$ for $96 \mathrm{~h}$ or single dose $(3.125 \mathrm{nM})$ of leptin for different time points (i.e., $24 \mathrm{~h}$, 48 h, 72 h, and 96 h). Following treatments, cell viability was measured using Crystal Violet Assay. As shown in Fig. 1, leptin treatment significantly promotes cell viability in MCF-7 and ZR-75-1 cells in a dose and timedependent fashion. The significant induction was first detected at $24 \mathrm{~h}$ with a dose of $3.125 \mathrm{nM}$. The effect was gradually increased with the increments of times and doses of leptin (Fig. 1a).

Except high dose $(31.25 \mathrm{nM})$, the leptin effect on cell viability was undetected in MDA-MB-231 cells even after the treatment of $96 \mathrm{~h}$. We found that $31.25 \mathrm{nM}$ dose of leptin treatment minimally but significantly reduced the viability of MDA-MB-231 cells while the effect was converse in MCF-7 and ZR-75-1 BC cell lines (Fig. 1a, bottom panel). Thus, this finding suggests that higher doses of leptin may act through a complex mechanism and cellular context dependent, which has not yet been elucidated.

\section{Leptin suppresses CCN5 expression at the transcriptional} level in ER-a-positive breast cancer cells

Recently, we found that CCN5-signaling is the driving force to prevent the growth and aggressive behavior of $\mathrm{BC}$ cells [44]. Thus, the goal of this study was to examine the effect of leptin on CCN5 expression in BC cells using qRT-PCR analysis. We found that the mRNA expression of CCN5 was significantly decreased in a doseand time-dependent fashion in leptin-treated ER- $\alpha$ and CCN5-positive MCF-7 cells as compared to vehicle a

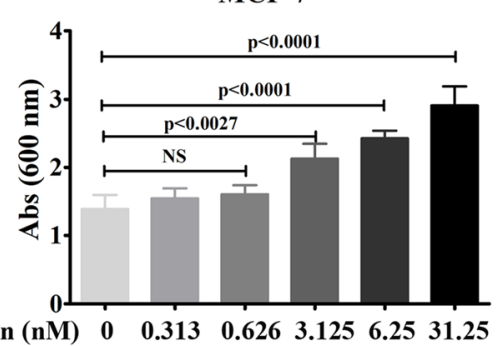

$\begin{array}{lllllll}\text { Leptin (nM) } & 0 & 0.313 & 0.626 & 3.125 & 6.25 & 31.25\end{array}$

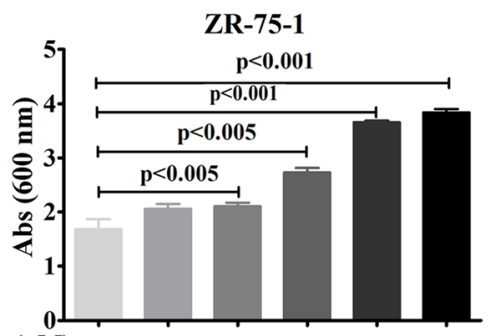

$\begin{array}{lllllll}\text { Leptin }(\mathrm{nM}) & 0 & 0.313 & 0.626 & 3.125 & 6.25 & 31.25\end{array}$

MDA-MB-231

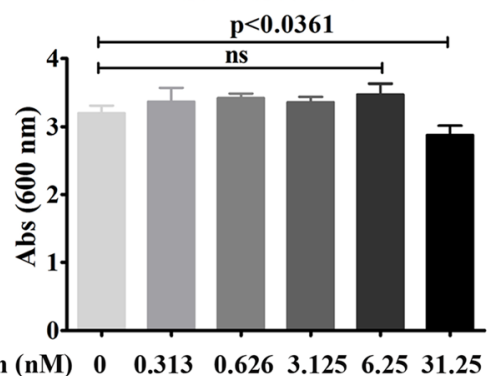

b

MCF-7

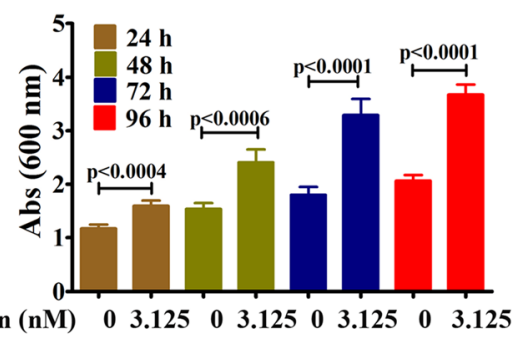

ZR-75-1

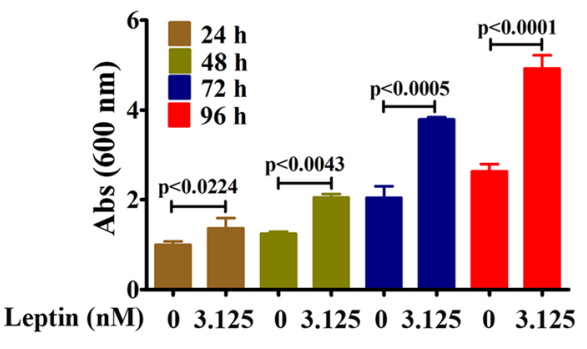

MDA-MB-231

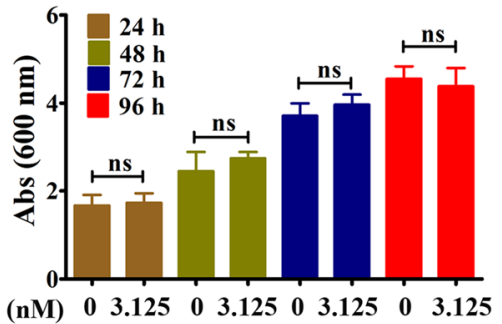

Fig. 1 Dose- and time-dependent effect of leptin on BC cell viability. a Dose-Dependent effect- 60-70\% confluent MCF-7, ZR-75-1 and MDA-MB-231 cells were grown in serum-deprived DMEM for $96 \mathrm{~h}$ in the presence or absence of different doses of Leptin and cell viability was measured using Crystal Violet assay. The data represents mean \pm SEM of eight independent experiments. b Time-dependent effect- $\sim 60-70 \%$ confluent MCF-7, ZR-75-1 and MDA-MB-231 cells were grown in serum-deprived DMEM for different times (i.e., $24 \mathrm{~h}, 48 \mathrm{~h}, 72 \mathrm{~h}$ and $96 \mathrm{~h}$ ) in the presence or absence of Leptin (3.125 nM) and cell viability was measured using Crystal Violet assay. The data represents mean \pm SEM of eight independent experiments 
treated cells (Fig. 2a and b). As expected, the effect of leptin with different doses was undetected in CCN5negative MDA-MB-231 cells (data not shown). To validate the above data, we further evaluated the effect of leptin on CCN5 mRNA and protein levels in MCF-7 and ZR-75-1 cells. To do so, Cells were grown to $60-70 \%$ confluences, serum starved for $24 \mathrm{~h}$ and then treated with leptin (3.125 $\mathrm{nM}$ ) or vehicle (PBS, controls) for 24 h. CCN5 mRNA levels were determined using Northern blotting and qRT-PCR, and CCN5 protein level was measured using Western blot analysis. Consistent with previous data, we found that both mRNA (Fig. $2 \mathrm{c}$ and d) and protein levels (Fig. 2e) of CCN5 were significantly decreased by leptin treatment. Based on the dose-dependent effects of leptin on cell viability and CCN5 expression in MCF-7 and ZR-75-1 cells, $3.125 \mathrm{nM}(50 \mathrm{ng} / \mathrm{ml})$ was considered for rest of the experiments.

Since both mRNA and protein expressions of CCN5 were affected by leptin, we determined whether leptininduced downregulation of CCN5 is mediated at the

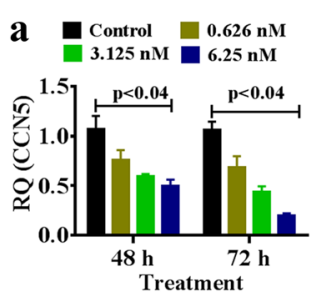

c
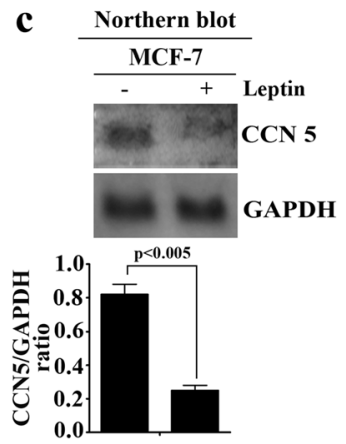

e

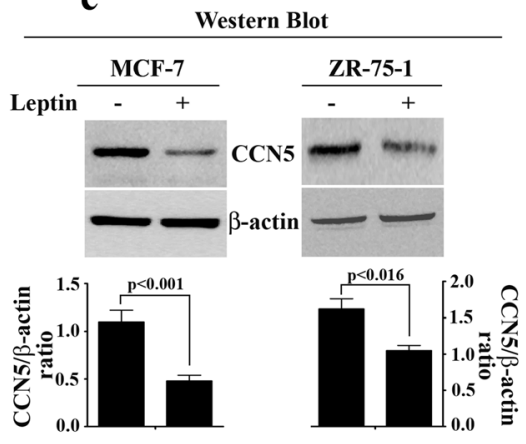

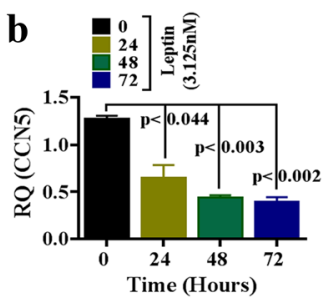

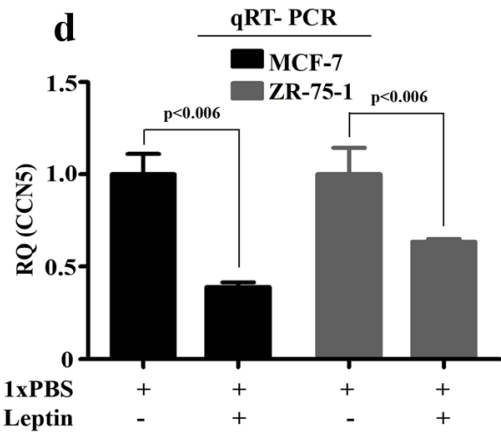

f
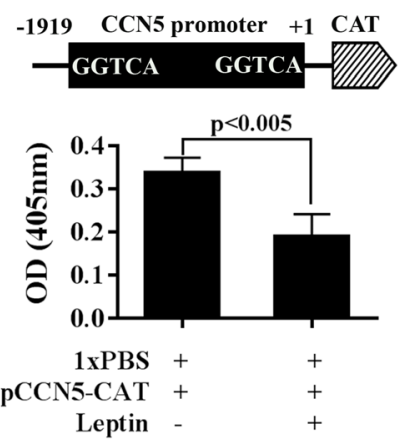

Fig. 2 CCN5 regulation by leptin in BC cells. $\mathbf{a}-\mathbf{b} \sim 60-70 \%$ confluent MCF-7 cells were serum deprived for $24 \mathrm{~h}$ and then cells were treated with different doses of leptin or different times with a fixed dose of leptin (3.125 nM). Total RNAs from treated and untreated cells were extracted and were subjected to qRT-PCR. Values on the barograph represent CCN5 expression changes in treated and untreated groups. The data represents mean \pm SEM of three independent experiments. c Serum deprived MCF-7 cells were grown in serum-deprived DMEM for $48 \mathrm{~h}$ in the presence or absence of Leptin (3.125 nM), and total RNAs from treated and untreated cells were extracted and were subjected to Northern blot analysis for CCN5 and GAPDH (loading control). Values on the barograph represent CCN5 expression changes in treated and untreated groups. The data represents mean \pm SEM of three independent experiments. $\mathbf{d}$ Serum deprived MCF-7 and ZR-75-1 cells were treated with leptin for $48 \mathrm{~h}$ as indicated above, and total RNA extracts were subjected to qRT-PCR analysis for CCN5. Values on the bargraph represent CCN5 expression changes in treated and untreated groups. The data represents mean \pm SEM of three independent experiments. e MCF-7 and ZR-75-1 cells treated with leptin (3.125 nM) for $48 \mathrm{~h}$, and whole cell extracts were subjected to immunoblot analysis for CCN5 and $\beta$-actin (loading control). Values on the bargraph represent CCN5 expression changes in treated and untreated groups. The data represents mean \pm SEM of three independent experiments. $\mathbf{f}$ MCF-7 cells were transiently transfected with CCN5/WISP-2 promoter. After $48 \mathrm{~h}$, transfected cells were grown in treated with $3.125 \mathrm{nM}$ leptin for $48 \mathrm{~h}$ or left untreated, and CAT assay was performed per the protocols indicated in Materials and Methods section. The results reflect the mean \pm SEM of 3 independent experiments 
transcriptional level via binding to CCN5 promoter. To do so, CCN5-CAT promoter constructs containing the 1.9-kb human CCN5 gene promoter sequence were transiently transfected into the MCF-7 cells using the Lipofectin $(20 \mu \mathrm{g} / \mathrm{ml})$ method [62]. The transfected cells were then exposed to leptin (3.125 nM) or 1xPBS alone for $48 \mathrm{~h}$. Cells were harvested, and cellular extracts were prepared for CAT assays. We found that CAT activity significantly impaired by leptin treatment as compared to PBS-treated samples (Fig. 2f).

Taken together, these results indicate that leptin suppresses CCN5 expression in ER- $\alpha$-positive breast cancer cells at the transcription level.

\section{Leptin-induced viability is impaired by CCN5 treatment}

We next determined whether suppression of CCN5 by leptin is a relevant episode in leptin-mediated ER- $\alpha$ positive breast cancer cell viability. MCF-7 and ZR-75-1 cells were first serum-starved for $24 \mathrm{~h}$ to synchronize cells, and then treated with leptin $(3.125 \mathrm{nM})$ or PBS for different time points in the presence or absence of hrCCN5 protein $(10.29 \mathrm{nM})$. The cell viability was assayed by crystal violet staining. Consistent with previous findings (Fig. 1), we found a time-dependent stimulatory effect of leptin on the cell viability of MCF-7 cells and ZR-75-1 cells (Fig. 3a and b), and the effect was significantly impaired when cells were concomitantly treated with leptin and hrCCN5 protein. Collectively, these studies indicate that leptin-induced ER- $\alpha$-positive breast cancer cell viability is mediated via suppressing CCN5 expression.

\section{Leptin suppresses apoptotic process to promote cell viability and this episode can be blocked by CCN5}

To study whether stimulation of cell viability by leptin is due to suppression of apoptosis, we performed ELISAbased apoptosis assay. Consistent with previous works, we found that $48 \mathrm{~h}$ leptin treatment suppressed the regular apoptosis occurred during in vitro cultured and suggesting that this episode may promote cell viability (Fig. 3c). Since the leptin effect on inhibition of apoptosis in MCF-7 and ZR-75-1 cells were not so dramatic as compared to the leptin effect on cell viability, we anticipate that other cell physiological factors could be
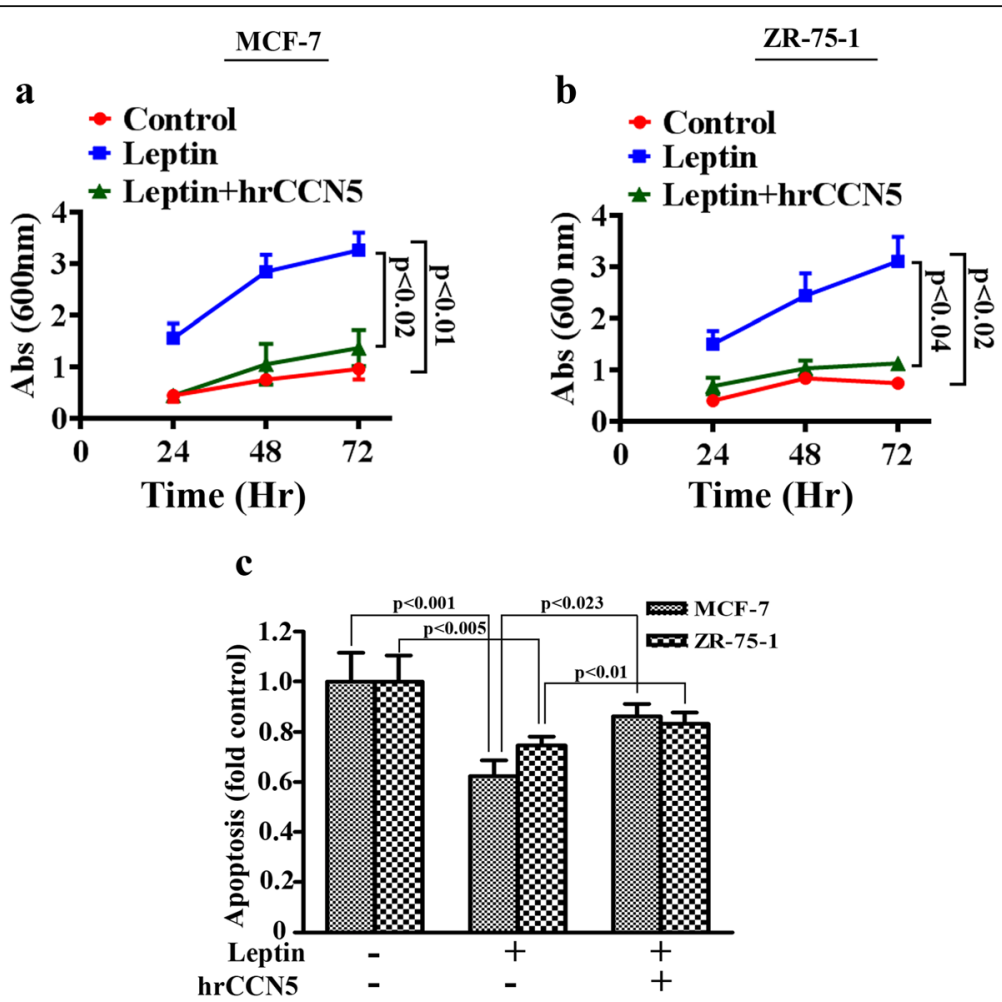

Fig. 3 Regulation of cell viability and apoptosis by leptin is mediated by CCN5. a-b BC Cells were grown for $24 \mathrm{~h}$ in a 96 - well plate under serum free condition. Cells were then treated with leptin (3.125 nM) or in combination of hrCCN5 (10.29 nM) in serum free media for 24 and 48 h. Cell viability was measured using crystal violet staining assay. Values on the bargraph represent the cell viability in treated and untreated groups. The data represents mean \pm SEM of three independent experiments. c MCF-7 cells were serum deprived for $24 \mathrm{~h}$ and then treated with leptin (3.125 $\mathrm{nM}$ ) in the presence or absence of hrCCN5 (10.29 nM) for $48 \mathrm{~h}$ under serum deprived conditions. Apoptotic cell death was determined using cell-death detection ELISA kit (detailed explanation in text). Values on the bargraph represent the apoptosis in treated and untreated groups. The data represents mean \pm SEM of eight independent experiments 
linked with leptin-induced cell viability. Furthermore, we found that hrCCN5 protein treatment significantly rescues cells from leptin-induced suppression of apoptosis (Fig. 3c).

\section{CCN5 protein treatment reprograms leptin-induced invasive phenotypes}

EMT is physiological and pathophysiological events in which epithelial cells are converted into mesenchymal cells for functional needs. In cancer, EMT contributes in early stage dissemination of cancer cells followed by invasion and metastasis $[70,71]$ as well as drug resistance [72]. The EMT process can be induced by leptin in BC cells [21]. Since CCN5 ablation promotes EMT and invasion in BC cells [38, 47, 51, 73, 74], we sought to determine whether leptin induces EMT via suppressing CCN5 in BC cells. As expected, exposure of MCF-7 cells to leptin resulted in up-regulation of mesenchymal marker (vimentin and snail) expressions accompanied by a marked decrease in E-cadherin (epithelial marker) (Fig. 4a and b). On the other hand, leptin-induced regulation of EMT markers can be impaired by concomitant treatment of hrCCN5 protein.

Next, we investigated whether these molecular changes affect the migratory behavior of breast cancer cells. To do so, MCF-7 and ZR-75-1 cells were treated with leptin or $1 \times$ PBS in the presence or absence of hrCCN5 for $48 \mathrm{~h}$ under appropriate experimental conditions (see Materials and Methods section). Cells were then seeded on the upper chamber of a Boyden chamber containing serum free DMEM, and after $24 \mathrm{~h}$, the migration of these cells to wards serum, which was added into the bottom chamber with DMEM, was determined. We found that the in vitro migration was significantly increased in leptin-treated MCF-7 and ZR-75-1 cells as compared to PBS-treated cells (Fig. 4b). However, $\mathbf{a}$

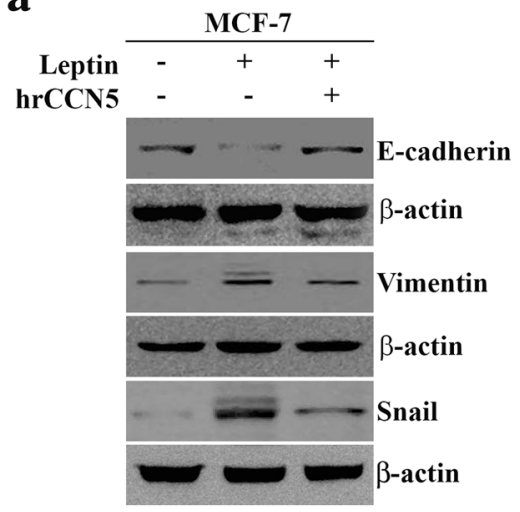

b

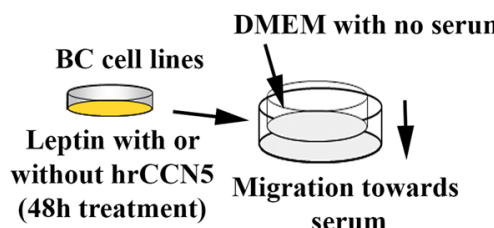

(DMEM with $10 \%$ serum)

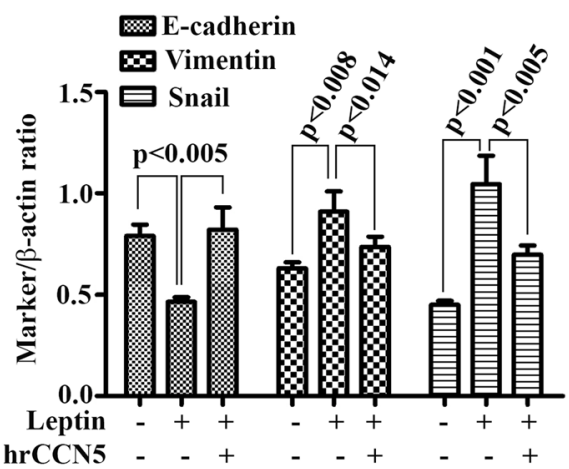

MCF-7

ZR-75-1 $p<0.001 \quad p<0.008$

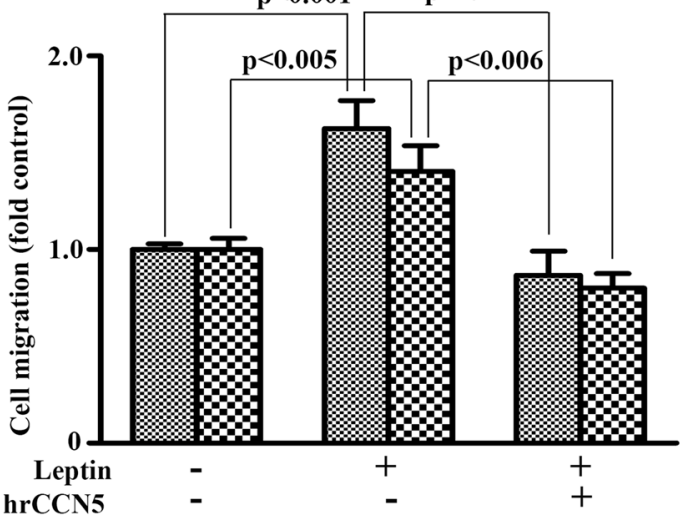

Fig. 4 hrCCN5 protein reprograms leptin-induced epithelial to mesenchymal transition and migratory behavior. a Equal amount of protein lysates of MCF-7 cells treated with leptin in the presence or absence of hrCCN5 was loaded on 7.5-10\% SDS-PAGE for the detection of EMT markers. A right panel shows the error bars which indicate mean $\pm \mathrm{SEM}$, and represents at least three independent experiments. $\mathbf{b}$ A diagram depicting experimental design to determine the leptin effect on BC cell migration in the presence or absence of hrCCN5 (left panel). MCF-7 and ZR-75-1 cells were treated with leptin in the presence or absence of hrCCN5 for $48 \mathrm{~h}$ and then seeded on the transwell filter insert of the modified Boyden chambers. Next day, the migrated cells were stained with crystal violet and quantitated on a microplate reader at 600 nm (right panel). The result is a representative of three independent experiments and displayed as mean \pm SEM 
leptin-induced migration was decreased to the basal level in the cells that were pre-exposed to hrCCN5 protein (Fig. 4b).

Taken together, these results indicate that leptin promotes EMT and migration of $\mathrm{BC}$ cells and that can be blocked by the treatment of CCN5 protein, suggesting CCN5 restoration could be beneficial for reversal of EMT via reprograming of gene-signatures.

\section{Leptin-induced mammosphere growth is nullified by CCN5 treatment}

Previous studies have shown that leptin enhances mammosphere forming ability of MCF-7 cells, and thus, suggested leptin helps in augmenting the cancer stem cell (CSCs)/tumor initiating cells (TICs) properties in less aggressive BC cells [21, 75]. We, therefore, determined whether CCN5-treatment blocks leptininduced CSCs/TICs properties in BC cells. Consistent with previous work, we found that leptin treatment significantly increased the number and sizes of mammosphere as compared to controls (Fig. 5). In contrast, CCN5 treatment significantly blocks the leptin-induced mammosphere formation by MCF-7 cells (Fig. 5). These data suggest that CCN5 ablation by leptin is a critical pathway to induce mammosphere formation by Non-aggressive and ER-positive breast cancer cells.

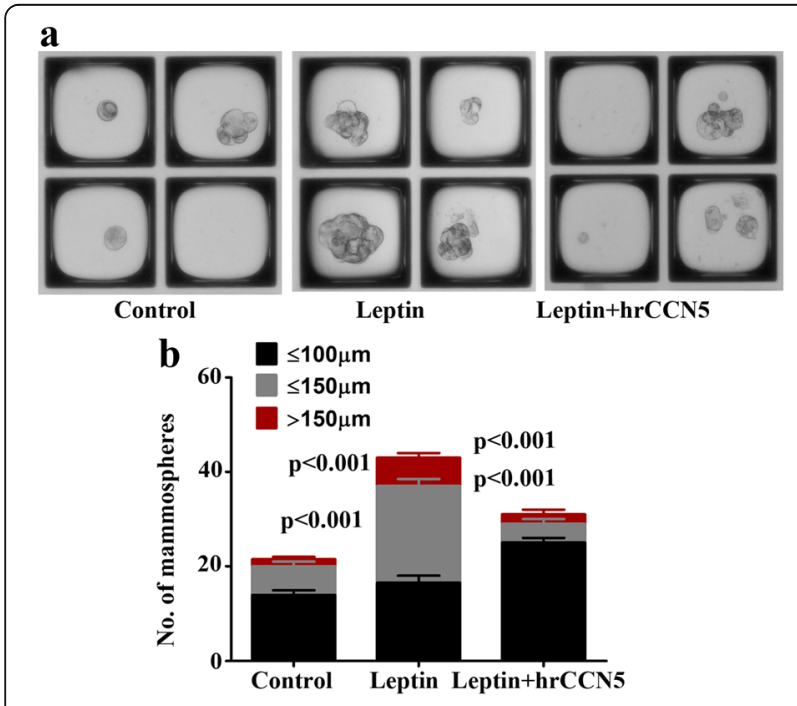

Fig. 5 hrCCN5 treatment suppresses the mammosphere forming ability of leptin treated MCF-7 cells. a Representative images of MCF-7-mammospheres following leptin (3.125 nM) treatment in the presence or absence of hrCCN5 (10.29 nM). b Bar graph represents the number of mammospheres of different sizes in the experimental set-up indicated. Error bars indicate mean \pm SEM of three independent experiments
CCN5 suppression by leptin is mediated by JAK/Akt/ STAT3-pathway

Leptin-induced growth and progression of $\mathrm{BC}$ cells are mediated via its receptor (Ob-R) that in turn can stimulate the signaling pathways like JAK/Stat3, ERK1/2, and PI3 Kinase/Akt [17-19, 21]. In this study, we sought to determine whether any of the above signaling pathways are involved in CCN5 suppression by leptin in BC cells. We first analyzed the effect of leptin on different signaling proteins including $\mathrm{p}$-STAT3, $\mathrm{p}$-AKT and p-ERK1/2 using Western blot analysis. Consistent with previous findings $[17-19,21]$, we found that the activities of all three signaling molecules were increased following leptin treatment in MCF-7 and ZR-75-1 cell lines (Fig. 6a). Next, we determined whether leptin-induced activation of these signaling mechanisms are linked with CCN5 suppression. To do so, we treated MCF-7 and ZR-75-1 cells with leptin in the presence or absence of pharmacological inhibitors of JAK2 (AG490), extracellular signal-regulated kinase (ERK) (U0126), or PI 3-kinase/ Akt (Wortmannin). We found that blocking JAK2 and AKT activities by inhibitors significantly impaired the inhibitory action of leptin on CCN5 expression in MCF-7 and ZR-75-1 cells (Fig. 6b). However, ERK-inhibitor was unable to rescue CCN5 from leptin-induced suppression in these cells (Fig. 6b, last lane). These inhibitors alone, except AKT-inhibitor, have no significant effects on CCN5 expression in these cell lines (Fig. 6c). AKTinhibitor induces CCN5 expression minimally but significantly in MCF-7 cells. Finally, to uncover the descending pathways, we determined the effects of JAKinhibitor on Akt-activity and other way around. We found that JAK-inhibitor significantly decreased Akt-and STAT3 activities. Similarly, AKT-inhibitor significantly diminished STAT3 as well as AKT activities in MCF-7 cells (Fig. 6c). However, consistent with previous work [76], STAT3 inhibitor (Niclosamide) does not impair AKT signaling in MCF-7 cells (data not shown). Therefore, these studies indicate that leptin blocks CCN5 expression via JAK/ Akt /STAT3 pathway in BC cells.

\section{Discussion}

Obesity is an established risk factor for $\mathrm{BC}$ in postmenopausal women. Current hypotheses suggest that leptin, which is also known as an obesity hormone or fat hormone, plays a vital role in $\mathrm{BC}$ development, and high serum leptin levels are associated with an increased risk for BC [77]. Leptin appears to be a very important factor in hormonal regulation of $\mathrm{BC}$ growth. However, the mechanism of leptin-induced BC development is unclear. This work shows that the growth and progression of luminal type (ER-positive) BC cells by leptin is mediated through sustained CCN5 suppression via activating JAK/ Akt / STAT3-signaling pathway (Fig. 7). 


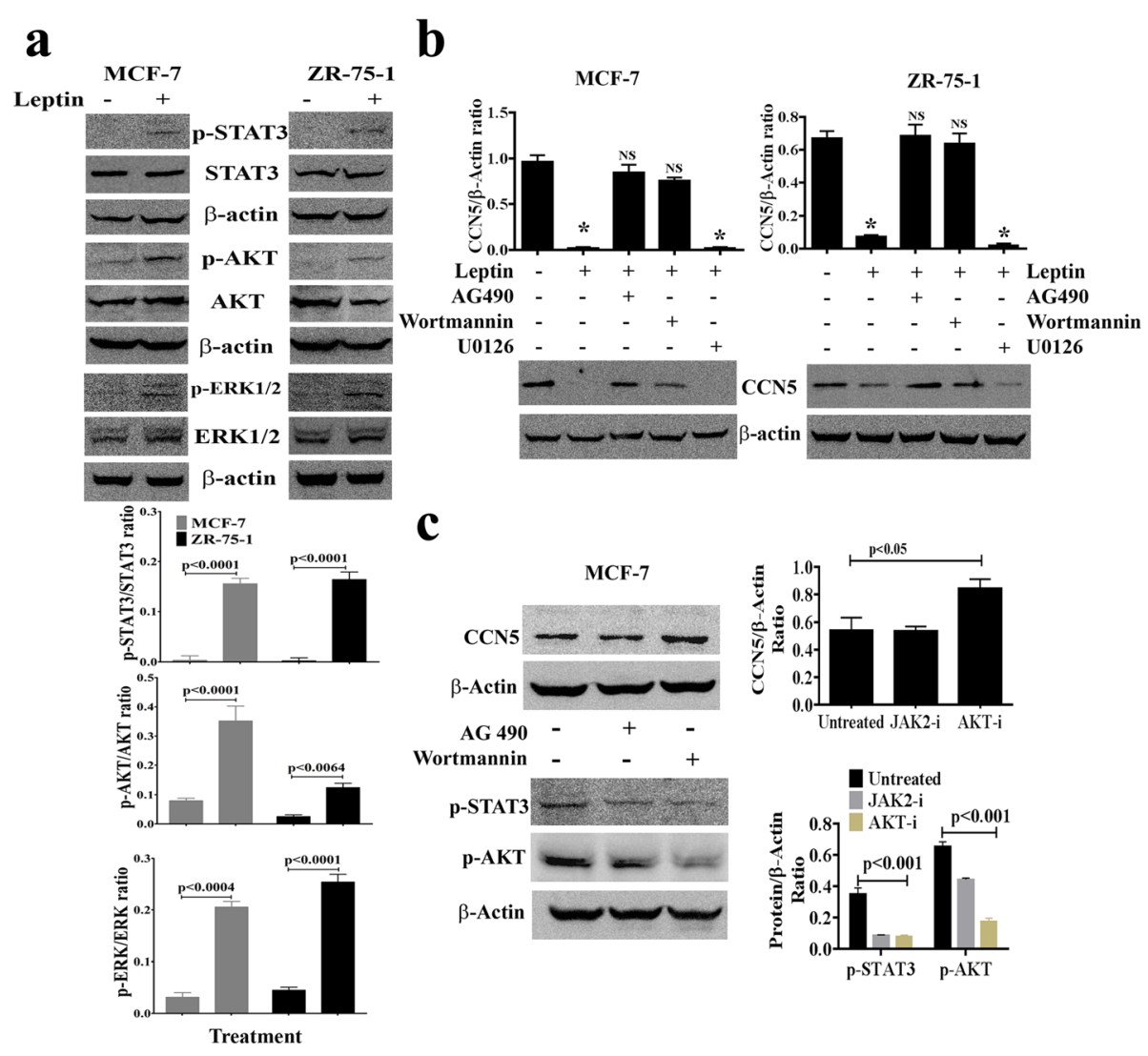

Fig. 6 Leptin promotes CCN5 expression via activation of JAK/STAT3/Akt signaling mechanism. a MCF-7 and ZR-75-1 cells were serum deprived for $24 \mathrm{~h}$ and then grown again in serum-deprived MDEM in the presence or absence of leptin $(3.215 \mathrm{nM})$ for $48 \mathrm{~h}$ and the status of phosphorylation of STAT3, p-AKT and p-ERK1/2 and constitutive expressions of these three proteins were measured using Western blot analysis. $\beta$-actin was used as loading controls. Error bars indicate mean \pm SEM of three independent experiments. b Semi-confluent ( 60-70\%) MCF-7 and ZR-75-1 cells were grown in serum-deprived MDEM for $24 \mathrm{~h}$, and then treated with different pharmacological inhibitors [AG-490 (100 $\mu \mathrm{M})$, Wortmannin $(20 \mu \mathrm{M})$ and U0126 $(10 \mu \mathrm{M})]$ for $1 \mathrm{~h}$. Following treatments of inhibitors, cells were grown in the presence or absence of leptin for $48 \mathrm{~h}$. CCN5 levels were measured in the cell extracts using Western blot analysis. The doses of the inhibitors are obtained from the vendors' instruction manuals. Error bars indicate mean \pm SEM of three independent experiments. NS, non-significant, ${ }^{*} p<0.0001$ vs control. c Effects of different inhibitors on CCN5 expression and activities of p-STAT3 and p-AKT in MCF-7 cells. Error bars indicate mean \pm SEM of three independent experiments. JAK2-i, JAK2-inhibitor and AKT-i, AKT-inhibitor

$\mathrm{BC}$ growth, progression and metastasis rely on multiple changes in gene-signature pattern, epigenome alterations and interactions between tumor and stromal cells [78-80]. Several endogenous factors are associated with the growth and progression of $\mathrm{BC}$. One of endogenous factors is leptin, which is secreted mainly from adipose tissue but also produced by other cells including cancerassociated fibroblasts and BC epithelial cells. Secreted leptin sustains short autocrine-paracrine loops and targets cancer epithelial cells to enhance their growth, motility and invasive behaviors [77]. Additionally, the secreted leptin promotes EMT, a hallmark of cancer progression, metastasis, and chemoresistance [21, 77, 81]. Thus, we can anticipate that sustained expression of leptin may promote aggressive behavior of BC cells. Mechanistically, although the multifaceted mechanisms have been proposed as driving $\mathrm{BC}$ growth and progression, the involvement of functionally active classical ER- $\alpha$ is debatable because classical ER- $\alpha$ expression in BC is an indicator of a good prognosis with less aggressive behaviors [82-84], where ER- $\alpha$ is dysfunctional in a metastatic micro-environment and is hormone resistant [85]. Thereby, we can anticipate an unhealthy cooperation between leptin and estrogen-signaling that might promote $\mathrm{BC}$ growth and progression with aggressive phenotypes. Given all the potential roles of leptin in BC progression, a novel mechanism of leptin is anticipated.

Multiple studies from our laboratory and others have shown that CCN5-signaling plays a vital role in orchestrating the growth and behavior of cancer cells. CCN5 acts as an anti-invasive element in cancer cells of the breast, pancreas and GI tract. [38, 41, 52, 55, 73, 74]. CCN5 is a $29-35 \mathrm{kDa}$ secreted protein with long halflife $(\sim 53 \mathrm{~h})$, and is overexpressed in preneoplastic 


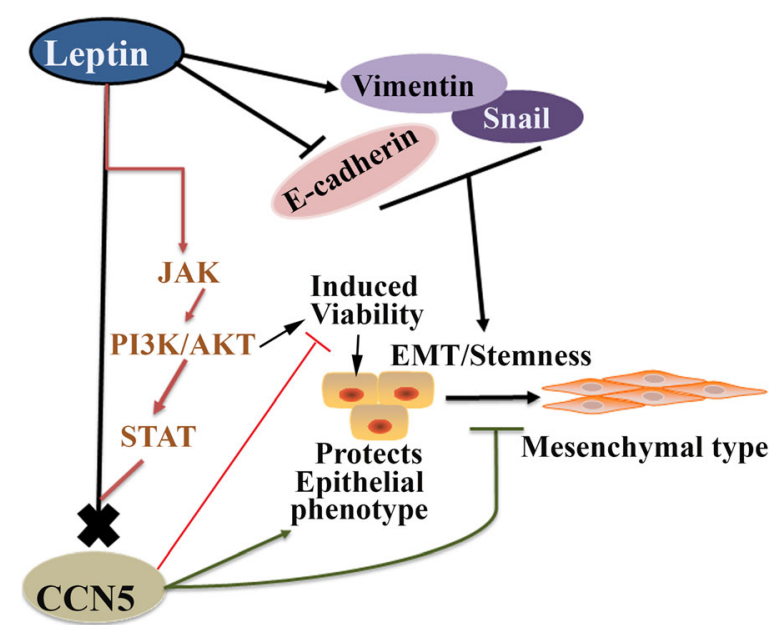

Fig. 7 A Model depicting the role of CCN5 on leptin-induced cell viability, EMT, cell migration and Stemness. Leptin blocks CCN5 expression via activating JAK AKT /STAT3-signaling in luminal (ER-positive) BC cells to promote cell viability and aggressive phenotypes of these cells

disorders in the human breast, including atypical ductal hyperplasia $(\mathrm{ADH})$ and ductal carcinoma in situ (DCIS) compared with adjacent invasive cancer cells where expression levels were undetected, minimally detected, or only sporadically detected [38]. Consistent with in vivo results, further studies have shown that CCN5 is differentially expressed in various breast tumor cell lines and its expression profile is varied depending on the microenvironment and the aggressive nature of the cells. For example, CCN5 is constitutively expressed in less aggressive human BC cells (i.e., MCF-7 and ZR-75-1), while its expression was minimally detected in the moderately aggressive BC cell line (i.e., SKBR3 ) and undetected in the highly aggressive $\mathrm{BC}$ cell line (i.e., MDA-MB-231). Our recent studies indicate that deficiency of the CCN5-driven program in $\mathrm{BC}$ promotes the growth of cancer cells and EMT, while upregulation of CCN5 is linked with ER- $\alpha$-activation in both normal and cancer cells of human and mouse breast $[44,58]$. Given all the roles of CCN5 in prevention of $\mathrm{BC}$ progression, our objective was to determine the role of CCN5 in leptin-signaling networks. Consistent with previous work, leptin has been found to promote $\mathrm{BC}$ cell viability via suppressing apoptosis (Fig. 3); it promotes cell migration and EMT in BC cells (Fig. 4). Furthermore, leptin promotes the mammosphere-forming ability of BC cells (Fig. 5). All these pathophiological events induced by leptin can be impaired by CCN5 treatment. Thus, this study reveals a mechanism by which leptin provokes the growth and progression of BC cells through suppressing CCN5-signaling.
The above findings raised an obvious and important question as to how leptin suppresses CCN5 expression in $\mathrm{BC}$ cells. Previously, multiple studies have shown that leptin mainly work through JAK/ERK/AKT/STAT3 pathway $[17-19,21]$. Thus, we assumed that the JAK /ERK/AKT/STAT signaling cascades could be involved in leptin-induced suppression of CCN5 expression in BC cells. Our studies support the hypothesis and indicate that CCN5 expression was suppressed by leptin via activating JAK/Akt/STAT3 pathway (Fig. 6). However, how STAT3, as a transcription factor, suppresses CCN5 in $\mathrm{BC}$ cells is unclear. It may directly interact with the CCN5 promoter and suppress CCN5 transcription or an intermediate pathway may involve in this event. Thus, further studies are warranted.

\section{Conclusions}

These studies suggest that CCN5 serves as a gatekeeper for leptin-dependent growth and progression of luminaltype (ER-positive) BC cells. Leptin may thus need to destroy the CCN5-barrier to promote BC growth and progression via activating JAK/AKT/STAT signaling. Therefore, our studies uncover a novel mechanism of leptin-signaling in driving $\mathrm{BC}$ growth and progression and shed new lights on improving anticancer therapy.

\section{Abbreviations}

ABTS: 2, 2'-azino-di-(3-ethyl-benzthiazoline-6-sulfonic acid); ADH: Atypical ductal hyperplasia; ATCC: American type culture collections; BC: Breast cancer; CAT: Chloramphenicol acetyltransferase; CCN: CTGF-Cyr61-Nov; CSC: Cancer stem cell; DCIS: Ductal carcinoma in situ; DMEM: Dulbecco's modified Eagle's medium; ECM: Extracellular matrix; EGFR: Epidermal growth factor receptor; EMT: Epithelial-mesenchymal transition; ER-a: Estrogen receptor-a; IGF: Insulin-like growth factor; Ob-R: Leptin receptor; PBS: Phosphate buffer saline; RQ: Relative quantification; SD: Standard deviation; TIC: Tumor initiating cells; VEGF: Vascular endothelial growth factor

\section{Acknowledgements}

We thank all the members of VA research office and Midwest Biomedical Research Foundation for their active support and Kim Folder for editing the manuscript.

\section{Funding}

This work is supported by VA Merit Grant (SKB), partly by other VA Merit Grant (SB) and Grace Hortense Greenley Trust, directed by The Research Foundation in memory of Eva Lee Caldwell (SKB and SK). The funding body had no role in the design of the study and collection, analysis, and interpretation of data and in writing the manuscript.

\section{Availability of data and materials}

All data generated and analyzed during the current studies are not publicly available due instructional restriction, but are available from the corresponding author on reasonable request.

\section{Authors' contributions}

$\boxplus H, A G, S A, S S$ and AR conducted the experiments. $I H, S B$ and SKB conceptualized the study and wrote the manuscript. $I H, A G, S K, S B$ and SKB assisted with the acquisition and analysis of the data. SB and SKB supervised the study. All authors revised the manuscript and approved its content.

\section{Authors' information}

Seth Acup: Summer research fellow in CRU, VAMC and a student (senior) from Missouri State University, Springfield, MO, 65897. 


\section{Ethics approval and consent to participate}

Not applicable

\section{Consent for publication}

Not applicable as no individual person's data are included in this manuscript.

\section{Competing interests}

The authors declare that they have no competing interests.

\section{Publisher's Note}

Springer Nature remains neutral with regard to jurisdictional claims in published maps and institutional affiliations.

\section{Author details}

Cancer Research Unit, VA Medical Center, Kansas City, MO, USA. ${ }^{2}$ Department of Medicine, University of Kansas Medical Center, Kansas City, KS, USA. ${ }^{3}$ Department of Anatomy and Cell Biology, University of Kansas Medical Center, Kansas City, KS, USA. ${ }^{4}$ Department of Pathology, University of Kansas Medical Center, Kansas City, KS, USA. ${ }^{5}$ Present Address: Syngene International Ltd, Clinical Development, Tower 1, Semicon Park, Phase II, Electronics City, Hosur Road, Bangalore, Karnataka 560100, India. ${ }^{6}$ Present Address: Saint James School of Medicine, Anguilla, British West Indies, USA. ${ }^{7}$ Cancer Research Unit, Research Division 151, VA Medical Center, 4801 Linwood Boulevard, Kansas City, MO 64128, USA.

\section{Received: 26 April 2017 Accepted: 16 January 2018}

\section{Published online: 25 January 2018}

\section{References}

1. Society Ac: American cancer Society. Cancer facts and Figures 2015. 2015th ed. Atlanta: American Cancer Society: www.cancer.org; 2015. p. 1-56.

2. DeSantis CE, Fedewa SA, Goding Sauer A, Kramer JL, Smith RA, Jemal A. Breast cancer statistics, 2015: convergence of incidence rates between black and white women. CA Cancer J Clin. 2016;66(1):31-42.

3. Siegel RL, Miller KD, Jemal A. Cancer statistics, 2015. CA Cancer J Clin. 2015; 65(1):5-29.

4. Winer A, Janosky M, Harrison B, Zhong J, Moussai D, Siyah P, Schatz-Siemers $\mathrm{N}$, Zeng J, Adams S, Mignatti P. Inhibition of breast cancer metastasis by Presurgical treatment with an oral matrix metalloproteinase inhibitor: a preclinical proof-of-principle study. Mol Cancer Ther. 2016;15(10):2370-7.

5. Beca F, Polyak K. Intratumor heterogeneity in breast cancer. Adv Exp Med Biol. 2016;882:169-89.

6. Campbell LL, Polyak K. Breast tumor heterogeneity: cancer stem cells or clonal evolution? Cell Cycle. 2007;6(19):2332-8.

7. Zhang M, Lee AV, Rosen JM. The cellular origin and evolution of breast cancer. Cold Spring Harb Perspect Med. 2017;7(3). doi: https://doi.org/10. 1101/cshperspect.a027128.

8. Cheraghi Z, Poorolajal J, Hashem T, Esmailnasab N, Doosti Irani A. Effect of body mass index on breast cancer during premenopausal and postmenopausal periods: a meta-analysis. PLoS One. 2012;7(12):e51446.

9. Kuhl $\mathrm{H}$. Breast cancer risk in the WHI study: the problem of obesity. Maturitas. 2005;51(1):83-97.

10. Wang X, Li L, Gao J, Liu J, Guo M, Liu L, Wang W, Wang J, Xing Z, Yu Z, et al. The association between body size and breast cancer in Han women in northern and eastern China. Oncologist. 2016. Epub ahead of print.

11. Saxena NK, Sharma D. Multifaceted leptin network: the molecular connection between obesity and breast cancer. J Mammary Gland Biol Neoplasia. 2013; 18(3-4):309-20.

12. Caan BJ, Kwan ML, Hartzell G, Castillo A, Slattery ML, Sternfeld B, Weltzien E. Pre-diagnosis body mass index, post-diagnosis weight change, and prognosis among women with early stage breast cancer. Cancer causes \& control : CCC. 2008;19(10):1319-28.

13. Litton JK, Gonzalez-Angulo AM, Warneke CL, Buzdar AU, Kau SW, Bondy M, Mahabir S, Hortobagyi GN, Brewster AM. Relationship between obesity and pathologic response to neoadjuvant chemotherapy among women with operable breast cancer. J Clin Oncol. 2008;26(25):4072-7.

14. Sanchez L, Lana A, Hidalgo A, Rodriguez JM, Del Valle MO, Cueto A Folgueras MV, Belyakova E, Comendador MA, Lopez ML. Risk factors for second primary tumours in breast cancer survivors. Eur J Cancer Prev. 2008;17(5):406-13.
15. Dirat B, Bochet $L$, Dabek M, Daviaud D, Dauvillier S, Majed B, Wang YY, Meulle A, Salles B, Le Gonidec S, et al. Cancer-associated adipocytes exhibit an activated phenotype and contribute to breast cancer invasion. Cancer Res. 2011;71(7):2455-65.

16. Pischon T, Nothlings U, Boeing H. Obesity and cancer. Proc Nutr Soc. 2008; 67(2):128-45.

17. Wang L, Tang C, Cao H, Li K, Pang X, Zhong L, Dang W, Tang H, Huang Y, Wei $L$, et al. Activation of IL-8 via PI3K/Akt-dependent pathway is involved in leptin-mediated epithelial-mesenchymal transition in human breast cancer cells. Cancer biology \& therapy. 2015;16(8):1220-30.

18. Wei L, Li K, Pang X, Guo B, Su M, Huang Y, Wang N, Ji F, Zhong C, Yang J, et al. Leptin promotes epithelial-mesenchymal transition of breast cancer via the upregulation of pyruvate kinase M2. J Exp Clin Cancer Res. 2016;35(1):166.

19. Saxena NK, Sharma D, Ding X, Lin S, Marra F, Merlin D, Anania FA. Concomitant activation of the JAK/STAT, PI3K/AKT, and ERK signaling is involved in leptinmediated promotion of invasion and migration of hepatocellular carcinoma cells. Cancer Res. 2007;67(6):2497-507.

20. Surmacz E. Obesity hormone leptin: a new target in breast cancer? Breast cancer research : BCR. 2007;9(1):301.

21. Yan D, Avtanski D, Saxena NK, Sharma D. Leptin-induced epithelial-mesenchymal transition in breast cancer cells requires beta-catenin activation via Akt/GSK3- and MTA1/Wnt1 protein-dependent pathways. J Biol Chem. 2012;287(11):8598-612.

22. Aliustaoglu M, Bilici A, Gumus M, Colak AT, Baloglu G, Irmak R, Seker M, Ustaalioglu BB, Salman T, Sonmez B, et al. Preoperative serum leptin levels in patients with breast cancer. Med Oncol. 2010;27(2):388-91.

23. Babaei Z, Moslemi D, Parsian H, Khafri S, Pouramir M, Mosapour A. Relationship of obesity with serum concentrations of leptin, CRP and IL-6 in breast cancer survivors. J Egypt Natl Canc Inst. 2015;27(4):223-9.

24. Harris HR, Tworoger SS, Hankinson SE, Rosner BA, Michels KB. Plasma leptin levels and risk of breast cancer in premenopausal women. Cancer Prev Res. 2011;4(9):1449-56.

25. Niu J, Jiang L, Guo W, Shao L, Liu Y, Wang L. The association between leptin level and breast cancer: a meta-analysis. PLoS One. 2013;8(6):e67349.

26. Fiorio E, Mercanti A, Terrasi M, Micciolo R, Remo A, Auriemma A, Molino A, Parolin V, Di Stefano B, Bonetti F, et al. Leptin/HER2 crosstalk in breast cancer: in vitro study and preliminary in vivo analysis. BMC Cancer. 2008;8:305.

27. Garofalo C, Koda M, Cascio S, Sulkowska M, Kanczuga-Koda L, Golaszewska Jusso A, Sulkowski S, Surmacz E. Increased expression of leptin and the leptin receptor as a marker of breast cancer progression: possible role of obesity-related stimuli. Clin Cancer Res. 2006;12(5):1447-53.

28. Ishikawa M, Kitayama J, Nagawa H. Enhanced expression of leptin and leptin receptor (OB-R) in human breast cancer. Clin Cancer Res. 2004;10(13):4325-31.

29. Catalano S, Marsico S, Giordano C, Mauro L, Rizza P, Panno ML, Ando S. Leptin enhances, via AP-1, expression of aromatase in the MCF-7 cell line. J Biol Chem. 2003:278(31):28668-76.

30. Geisler J, Haynes B, Ekse D, Dowsett M, Lonning PE. Total body aromatization in postmenopausal breast cancer patients is strongly correlated to plasma leptin levels. J Steroid Biochem Mol Biol. 2007;104(1-2):27-34.

31. Magoffin DA, Weitsman SR, Aagarwal SK, Jakimiuk AJ. Leptin regulation of aromatase activity in adipose stromal cells from regularly cycling women. Ginekol Pol. 1999:70(1):1-7.

32. Catalano S, Mauro L, Marsico S, Giordano C, Rizza P, Rago V, Montanaro D Maggiolini M, Panno ML, Ando S. Leptin induces, via ERK1/ERK2 signal, functional activation of estrogen receptor alpha in MCF-7 cells. J Biol Chem. 2004:279(19):19908-15.

33. Sulkowska M, Golaszewska J, Wincewicz A, Koda M, Baltaziak M, Sulkowski S. Leptin-from regulation of fat metabolism to stimulation of breast cancer growth. Pathology oncology research : POR. 2006;12(2):69-72.

34. Gonzalez RR, Cherfils S, Escobar M, Yoo JH, Carino C, Styer AK, Sullivan BT, Sakamoto H, Olawaiye A, Serikawa T, et al. Leptin signaling promotes the growth of mammary tumors and increases the expression of vascular endothelial growth factor (VEGF) and its receptor type two (VEGF-R2). J Biol Chem. 2006;281(36):26320-8

35. Saxena NK, Taliaferro-Smith L, Knight BB, Merlin D, Anania FA, O'Regan RM, Sharma D. Bidirectional crosstalk between leptin and insulin-like growth factor-I signaling promotes invasion and migration of breast cancer cells via transactivation of epidermal growth factor receptor. Cancer Res. 2008;68(23): 9712-22.

36. Perera CN, Chin HG, Duru N, Camarillo IG. Leptin-regulated gene expression in MCF-7 breast cancer cells: mechanistic insights into leptin-regulated mammary tumor growth and progression. J Endocrinol. 2008;199(2):221-33. 
37. Brigstock DR. The connective tissue growth factor//ysteine-rich $61 /$ nephroblastoma overexpressed (CCN) family. Endocr Rev. 1999;20(2):189-206.

38. Banerjee SK, Banerjee S. CCN5/WISP-2: a micromanager of breast cancer progression. J Cell Commun Signal. 2012;6(2):63-71.

39. Perbal B. The CCN family of genes: a brief history. Molecular pathology : MP. 2001;54(2):103-4.

40. Jun JI, Lau LF. Taking aim at the extracellular matrix: CCN proteins as emerging therapeutic targets. Nat Rev Drug Discov. 2011;10(12):945-63.

41. Russo JW, Castellot JJ. CCN5: biology and pathophysiology. J Cell Commun Signal. 2010;4(3):119-30.

42. Wiesman KC, Wei L, Baughman C, Russo J, Gray MR, Castellot JJ. CCN5, a secreted protein, localizes to the nucleus. J Cell Commun Signal. 2010;4(2):91-8.

43. Pennica D, Swanson TA, Welsh JW, Roy MA, Lawrence DA, Lee J, Brush J, Taneyhill LA, Deuel B, Lew M, et al. WISP genes are members of the connective tissue growth factor family that are up-regulated in wnt-1-transformed cells and aberrantly expressed in human colon tumors. ProcNat|AcadSciUSA. 1998;95(25): $14717-22$.

44. Das A, Dhar K, Maity G, Sarkar S, Ghosh A, Haque I, Dhar G, Banerjee S, Banerjee SK. Deficiency of CCN5/WISP-2-driven program in breast cancer promotes cancer epithelial cells to mesenchymal stem cells and breast cancer growth. Sci Rep. 2017;7(1):1220.

45. Banerjee S, Sengupta K, Saxena NK, Dhar K, Banerjee SK. Epidermal growth factor induces WISP-2/CCN5 expression in estrogen receptor-alpha-positive breast tumor cells through multiple molecular cross-talks. MolCancer Res. 2005:3(3):151-62.

46. Fritah A, Redeuilh G, Sabbah M. Molecular cloning and characterization of the human WISP-2/CCN5 gene promoter reveal its upregulation by oestrogens. J Endocrinol. 2006;191(3):613-24.

47. Fritah A, Saucier C, De Wever O, Bracke M, Bieche I, Lidereau R, Gespach C, Drouot S, Redeuilh G, Sabbah M. Role of WISP-2/CCN5 in the maintenance of a differentiated and noninvasive phenotype in human breast cancer cells. Mol Cell Biol. 2008:28(3):1114-23.

48. Sabbah M, Prunier C, Ferrand N, Megalophonos V, Lambein K, De Wever O, Nazaret N, Lachuer J, Dumont S, Redeuilh G. CCN5, a novel transcriptional repressor of the transforming growth factor beta signaling pathway. Mol Cell Biol. 2011;31(7):1459-69.

49. Ferrand N, Stragier E, Redeuilh G, Sabbah M. Glucocorticoids induce CCN5/ WISP-2 expression and attenuate invasion in oestrogen receptor-negative human breast cancer cells. The Biochemical journal. 2012;447(1):71-9.

50. Fuady JH, Bordoli MR, Abreu-Rodriguez I, Kristiansen G, Hoogewijs D, Stiehl DP, Wenger RH. Hypoxia-inducible factor-mediated induction of WISP-2 contributes to attenuated progression of breast cancer. Hypoxia. 2014;2:23-33.

51. Dhar G, Mehta S, Banerjee S, Gardner A, McCarty BM, Mathur SC, Campbell DR, Kambhampati S, Banerjee SK. Loss of WISP-2/CCN5 signaling in human pancreatic cancer: a potential mechanism for epithelial-mesenchymaltransition. Cancer Lett. 2007;254(1):63-70.

52. Banerjee SK, Maity G, Haque I, Ghosh A, Sarkar S, Gupta V, Campbell DR, Von Hoff D, Banerjee S. Human pancreatic cancer progression: an anarchy among CCN-siblings. J Cell Commun Signal. 2016;10(3):207-16.

53. Kouzu Y, Uzawa K, Kato M, Higo M, Nimura Y, Harada K, Numata T, Seki N, Sato M, Tanzawa H. WISP-2 expression in human salivary gland tumors. Int J Mol Med. 2006;17(4):567-73.

54. Yang Z, Yang Z, Zou Q, Yuan Y, Li J, Li D, Liang L, Zeng G, Chen S. A comparative study of clinicopathological significance, FGFBP1, and WISP-2 expression between squamous cell/adenosquamous carcinomas and adenocarcinoma of the gallbladder. Int J Clin Oncol. 2014;19(2):325-35.

55. Ji J, Jia S, Jia Y, Ji K, Hargest R, Jiang WG. WISP-2 in human gastric cancer and its potential metastatic suppressor role in gastric cancer cells mediated by JNK and PLC-gamma pathways. Br J Cancer. 2015;113(6):921-33.

56. Dhar G, Banerjee S, Dhar K, Tawfik O, Mayo MS, Vanveldhuizen PJ, Banerjee SK. Gain of oncogenic function of p53 mutants induces invasive phenotypes in human breast cancer cells by silencing CCN5/MISP-2. Cancer Res. 2008;68(12):4580-7.

57. Haque I, Banerjee S, Mehta S, De A, Majumder M, Mayo MS, Kambhampati S, Campbell DR, Banerjee SK. Cysteine-rich 61-connective tissue growth factornephroblastoma-overexpressed 5 (CCN5)/Wnt-1-induced signaling protein-2 (WISP2) regulates microRNA-10b via hypoxia-inducible factor-1alpha-TWIST signaling networks in human breast cancer cells. JBiolChem. 2011;286(50):43475-85.

58. Sarkar S, Ghosh A, Banerjee S, Maity G, Das A, Larson MA, Gupta V, Haque I, Tawfik O, Banerjee SK. CCN5/WISP-2 restores ER- proportional, variant in normal and neoplastic breast cells and sensitizes triple negative breast cancer cells to tamoxifen. Oncogene. 2017;6(5):e340.
59. Maity G, De A, Das A, Banerjee S, Sarkar S, Banerjee SK. Aspirin blocks growth of breast tumor cells and tumor-initiating cells and induces reprogramming factors of mesenchymal to epithelial transition. Lab Investig. 2015;95(7):702-17.

60. Feoktistova M, Geserick P, Leverkus M. Crystal Violet Assay for Determining Viability of Cultured Cells. Cold Spring Harb Protoc. 2016;2016(4):pdb prot087379.

61. Ray G, Dhar G, Van Veldhuizen PJ, Banerjee S, Saxena NK, Sengupta K, Banerjee SK. Modulation of cell-cycle regulatory signaling network by 2methoxyestradiol in prostate cancer cells is mediated through multiple signal transduction pathways. Biochemistry. 2006;45(11):3703-13.

62. Banerjee S, Sengupta K, Saxena NK, Dhar K, Banerjee SK. Epidermal growth factor induces WISP-2/CCN5 expression in estrogen receptor-alpha-positive breast tumor cells through multiple molecular cross-talks. Mol Cancer Res. 2005;3(3):151-62.

63. Banerjee S, Saxena N, Sengupta K, Tawfik O, Mayo MS, Banerjee SK. WISP-2 gene in human breast cancer: estrogen and progesterone inducible expression and regulation of tumor cell proliferation. Neoplasia. 2003;5(1):63-73.

64. Livak KJ, Schmittgen TD. Analysis of relative gene expression data using real-time quantitative PCR and the 2(-Delta Delta C(T)) method. Methods. 2001;25(4):402-8.

65. Banerjee S, Dhar G, Haque I, Kambhampati S, Mehta S, Sengupta K, Tawfik O, Phillips TA, Banerjee SK. CCN5/WISP-2 expression in breast adenocarcinoma is associated with less frequent progression of the disease and suppresses the invasive phenotypes of tumor cells. Cancer Res. 2008;68(18):7606-12.

66. Huang S, New L, Pan Z, Han J, Nemerow GR. Urokinase plasminogen activator/urokinase-specific surface receptor expression and matrix invasion by breast cancer cells requires constitutive p38alpha mitogen-activated protein kinase activity. J Biol Chem. 2000;275(16):12266-72.

67. Noether GE. Sample size determination for some common nonparametric tests. J Am Stat Assoc. 1987;82(398):645-7.

68. Dieudonne MN, Machinal-Quelin F, Serazin-Leroy V, Leneveu MC, Pecquery R, Giudicelli Y. Leptin mediates a proliferative response in human MCF7 breast cancer cells. Biochem Biophys Res Commun. 2002;293(1):622-8.

69. Strong AL, Ohlstein JF, Biagas BA, Rhodes LV, Pei DT, Tucker HA, Llamas C, Bowles AC, Dutreil MF, Zhang S, et al. Leptin produced by obese adipose stromal/stem cells enhances proliferation and metastasis of estrogen receptor positive breast cancers. Breast Cancer Res. 2015;17:112.

70. Rhim AD, Mirek ET, Aiello NM, Maitra A, Bailey JM, McAllister F, Reichert M, Beatty GL, Rustgi AK, Vonderheide RH, et al. EMT and dissemination precede pancreatic tumor formation. Cell. 2012;148(1-2):349-61.

71. Kalluri R, Weinberg RA. The basics of epithelial-mesenchymal transition. J Clin Invest. 2009;119(6):1420-8.

72. Zheng X, Carstens JL, Kim J, Scheible M, Kaye J, Sugimoto H, Wu CC, LeBleu VS, Kalluri R. Epithelial-to-mesenchymal transition is dispensable for metastasis but induces chemoresistance in pancreatic cancer. Nature. 2015;527(7579):525-30.

73. Haque I, Banerjee S, De A, Maity G, Sarkar S, Majumdar M, Jha SS, McGragor D, Banerjee SK. CCN5/WISP-2 promotes growth arrest of triple-negative breast cancer cells through accumulation and trafficking of p27(Kip1) via Skp2 and FOXO3a regulation. Oncogene. 2015;34(24):3152-63.

74. Haque I, Banerjee S, Mehta S, De A, Majumder M, Mayo MS, Kambhampati S, Campbell DR, Banerjee SK. Cysteine-rich 61-connective tissue growth factor-nephroblastoma-overexpressed 5 (CCN5)/Wnt-1-induced signaling protein-2 (WISP-2) regulates microRNA-10b via hypoxia-inducible factor1alpha-TWIST signaling networks in human breast cancer cells. J Biol Chem. 2011;286(50):43475-85.

75. Giordano C, Chemi F, Panza S, Barone I, Bonofiglio D, Lanzino M, Cordella A, Campana A, Hashim A, Rizza P et al: Leptin as a mediator of tumor-stromal interactions promotes breast cancer stem cell activity. Oncotarget 2016, 7(2):1262-1275.

76. Fonseca BD, Diering GH, Bidinosti MA, Dalal K, Alain T, Balgi AD, Forestieri R, Nodwell M, Rajadurai CV, Gunaratnam C, et al. Structure-activity analysis of niclosamide reveals potential role for cytoplasmic $\mathrm{pH}$ in control of mammalian target of rapamycin complex 1 (mTORC1) signaling. J Biol Chem. 2012;287(21): 17530-45.

77. Ando S, Barone I, Giordano C, Bonofiglio D, Catalano S. The multifaceted mechanism of leptin signaling within tumor microenvironment in driving breast cancer growth and progression. Front Oncol. 2014:4:340.

78. Dawson MA. The cancer epigenome: concepts, challenges, and therapeutic opportunities. Science. 2017;355(6330):1147-52.

79. Horning SJ. A new cancer ecosystem. Science. 2017;355(6330):1103.

80. Hanahan D, Weinberg RA. Hallmarks of cancer: the next generation. Cell. 2011;144(5):646-74. 
81. Mallini P, Lennard T, Kirby J, Meeson A. Epithelial-to-mesenchymal transition: what is the impact on breast cancer stem cells and drug resistance. Cancer Treat Rev. 2014;40(3):341-8.

82. Ali S, Coombes RC. Estrogen receptor alpha in human breast cancer: occurrence and significance. J Mammary Gland Biol Neoplasia. 2000;5(3): 271-81.

83. Ali SH, O'Donnell AL, Balu D, Pohl MB, Seyler MJ, Mohamed S, Mousa S, Dandona P. Estrogen receptor-alpha in the inhibition of cancer growth and angiogenesis. Cancer Res. 2000;60(24):7094-8.

84. Duffy MJ. Estrogen receptors: role in breast cancer. Crit Rev Clin Lab Sci. 2006:43(4):325-47.

85. Harrell JC, Dye WW, Allred DC, Jedlicka P, Spoelstra NS, Sartorius CA, Horwitz KB. Estrogen receptor positive breast cancer metastasis: altered hormonal sensitivity and tumor aggressiveness in lymphatic vessels and lymph nodes. Cancer Res. 2006;66(18):9308-15.

Submit your next manuscript to BioMed Central and we will help you at every step:

- We accept pre-submission inquiries

- Our selector tool helps you to find the most relevant journal

- We provide round the clock customer support

- Convenient online submission

- Thorough peer review

- Inclusion in PubMed and all major indexing services

- Maximum visibility for your research

Submit your manuscript at www.biomedcentral.com/submit 